\title{
Impacto Regional del Desarrollo de Bioenergía (Biomasa) en Argentina. Un análisis Insumo-Producto para la provincia de Misiones
}

Regional Impact of Bioenergy Development (Biomass) in Argentina. An Input-Output Analysis for the Province of Misiones Impacto regional do Desenvolvimento da Bioenergia (Biomassa) na Argentina. Uma análise de insumo-produto para a província de Misiones

\section{Lorenzo Perrotta}

Universidad de Buenos Aires, Argentina

E-mail: loren.perrotta@gmail.com

Fecha de recepción: 10/12/2020 Fecha de aceptación: 28/02/2021

Palabras clave

- Desarrollo de Bioenergía

- Biomasa

- Modelo insumo-producto

- Modelo Regional - Misiones (Argentina)

- Beneficio Social Neto

\section{Resumen}

Dado que los patrones actuales de consumo y producción de energía están estresando severamente los sistemas naturales y sociales, se requiere no solo una mejora de eficiencia energética sino también una producción de energía ambientalmente sostenible. En este contexto, el uso de biomasa como fuente renovable de generación de energía podría permitir una producción de energía limpia, particularmente en regiones donde existe una ventaja comparativa natural y donde el acceso a otras fuentes de energía es costoso. Este es el caso de Misiones, una provincia de la Argentina, que muestra un alto potencial para la producción de energía a través de la biomasa de su actividad forestal. El objetivo principal de este trabajo es evaluar el beneficio social neto del desarrollo y la inversión (tecnología, infraestructura, etc.) en bioenergía a partir de biomasa en esta provincia. Para eso, se ha desarrollado un modelo insumo-producto regional para Misiones que permite analizar el impacto de distintos escenarios sobre el nivel de empleo y producción provincial. Se simulan tres escenarios: uno en el que se aumenta la producción de bioenergía, otro en el que la capacidad de producción existente se expande a través de inversiones y, finalmente, se valoran los costos de producción e inversión necesa- 
Keywords

- Bioenergy development

- Biomass

- Input-Output model

- Regional model - Misiones (Argentina)

- Net Social Benefit rios para expandir la producción a niveles potenciales. Los resultados muestran grandes efectos tanto en la producción como en la generación de empleo provincial en todos los escenarios, alcanzando los mayores impactos en aquellos escenarios en los cuales se realizan inversiones con componentes locales, logrando capturar los efectos positivos dentro de la provincia. Las conclusiones proporcionan algunas recomendaciones de política para impulsar el desarrollo de la biomasa como fuente de generación de energía en Argentina dado que las regulaciones y programas actuales en el sector no están orientados regionalmente.

\section{Abstract}

Since current patterns of energy consumption and production are severely stressing natural and social systems, it is necessary not only to improve energy efficiency but also to produce energy in an environmentally sustainable way. In this context, the use of biomass as a renewable source of energy generation could allow clean energy production, particularly in regions where there is a natural comparative advantage and where the access to other sources of energy is expensive. This is the case of Misiones, a province in Argentina, which displays a high potential for energy production through biomass from its forestry activity. The main objective of this paper is to evaluate the net social benefit of the development and the investment (technology, infrastructure, etc.) in bioenergy from biomass in this province. For this evaluation, a regional input-output model for Misiones has been developed. It allows the analysis of the impact of different scenarios on the level of employment and provincial production to be carried out. Three scenarios have been simulated: one in which energy production is increased, another one in which the existing production capacity is expanded through investments and, finally, the production and investment costs needed to expand production to potential levels are valued. Results have shown a great impact on both production and job creation in all the scenarios, reaching the greatest level of impact in those scenarios in which investments are made with local components, managing to capture the positive effects within the province. The conclusions provide some policy recommendations for boosting the development of biomass as a source for energy generation in Argentina since current regulations and programs in the sector are not regionally oriented.

\section{Resumo}

Dado que os atuais padrões de consumo e produção de energia estão estressando gravemente os sistemas naturais e sociais, é necessária não apenas a melhoria da eficiência energética mas também a produção de energia ambientalmente sustentável. Neste contexto, a utilização da biomassa como fonte renovável de geração de energia poderia permitir uma 
Palavras-chave

- Desenvolvimento da Bioenergia

- Biomassa

- Modelo Insumo-produto Modelo Regional - Misiones (Argentina)

- Benefício Social Líquido produção de energia limpa, principalmente em regiões onde existe uma vantagem comparativa natural e onde 0 acesso a outras fontes de energia é custoso. É 0 caso de Misiones, uma província da Argentina, que apresenta um alto potencial para a produção de energia através da biomassa da sua atividade florestal. 0 objetivo principal deste trabalho é avaliar 0 benefício social líquido do desenvolvimento e o investimento (tecnologia, infraestrutura, etc.) em bioenergia nesta província a partir de biomassa. Para tanto, foi desenvolvido um modelo de insumo-produto regional para Misiones, que permite analisar 0 impacto de diferentes cenários sobre o nível de emprego e produção provincial. Simulam-se três cenários: um no que é aumentada a produção de energia, outro no que é expandida a capacidade de produção existente através de investimentos e, por fim, são avaliados os custos de produção e de investimento necessários para expandir a produção aos níveis potenciais. 0 s resultados mostram grandes efeitos tanto na produção quanto na geração de emprego em todos os cenários, atingindo os maiores impactos naqueles nos que os investimentos são feitos com componentes locais, conseguindo captar os efeitos positivos dentro da província. As conclusões fornecem algumas recomendações de política para impulsionar o desenvolvimento da biomassa como fonte de geração de energia na Argentina, visto que os atuais regulamentos e programas para 0 setor não são orientados regionalmente. 